\title{
NUTRITIONAL SITUATION OF CHILDREN UNDER FIVE YEARS OLD IN BRAZIL'S NORTHEASTERN CITIES
}

\author{
Alice Teles de Carvalho', Erika Rodrigues de Almeida1, Eduardo Augusto Fernandes Nilson², \\ Juliana Amorim Ubarana ${ }^{2}$, Janine Giuberti Coutinho², Rodrigo Pinheiro de Toledo Vianna ${ }^{1}$, \\ Flávia Emília Leite de Lima ${ }^{1}$
}

\begin{abstract}
OBJECTIVE: To describe the nutritional situation of children under five years old resident in three cities of Brazil's northeastern region. METHODS: A transversal epidemiological study was undertaken with the participation of 1,378 children. The anthropometric measurements height/age, weight/age and weight/height were calculated in terms of the Z score. Children's growth curves of the World Health Organization were used as reference. RESULTS: Higher proportions were found of overweight/ height (8.3\% in Barra de São Miguel, $10.3 \%$ in Cabedelo and 5.9\% in Tibau do Sul) than of deficit (1.5\% in Barra de São Miguel, $1.9 \%$ in Cabedelo and $0.9 \%$ in Tibau do Sul). A higher prevalence of the height deficit was observed (5.9\% in Barra de São Miguel, 5.5\% in Cabedelo and 4.6\% in Tibau do Sul) than of the weight deficit (3.6\% in Barra de São Miguel, $2.5 \%$ in Cabedelo and 1.5\% in Tibau do Sul). CONCLUSION: The nutritional status of the group studied was unfavorable. Actions to promote adequate eating habits within the context of food and nutrition programs and policies should, therefore, be prioritized. The high prevalence of height deficit and overweight highlights the vulnerability of this group and the sum of the necessary actions should produce an impact by reversing this nutritional profile.
\end{abstract}

Key words: nutritional status, anthropometry, child, obesity, stature for age.

\section{INTRODUCTION}

The nutritional transition may be understood as the passage from a model characterized by the occurrence of serious forms of overall deficiencies (kwashiokor, nutritional marasmus) or specific lacks (hipovitaminosis A, scurvy, beriberi, rickets, osteomalacia, pellagra, anemia), constituting manifestations of dominant acute character, to another in which non-transmissible chronic diseases predominate, associated with overweight/obesity, dyslipoproteinemia dyslipidemias, the metabolic syndrome which antecedes type 2 diabetes milletus, to hyperuricemia and other manifestations or factors of less serious risk ${ }^{1}$.

The process of nutritional transition arises from modifications in the pattern of feeding and consumption which accompany economic, social and demographic changes, and from the profile of the health of populations, that is to say, from a tendency to modify the consumption, the production and the commercialization of foodstuffs - as also the lifestyle - which has been occurring mainly in the peripheral capitalistic countries ${ }^{2}$.

Various authors have studied the nutritional transition in Latin America and sought to identify its relationship with the demographical/ epidemiological transition, and have observed distinct moments in this process as between the various countries. In general, the nutritional transition in the infant population of the Latin American countries is characterized by the increase in the prevalence of overweight and obesity and a reduction in the prevalence of under-weight, a deficit in stature still persisting in high proportions ${ }^{3-7}$.

In Brazil, this specific transition in the nutrition field takes place within a context which includes rapid urbanization, a substantial decline in the birth-rate as from the $70 \mathrm{~s}$, with a resulting reduction in the size of the family, the social and professional ascendancy of women, an improvement in sanitary conditions, victory over infectious diseases, the new profile of the work market with the increase in schooling, the socialization of information, the more ample access to health services and actions, and the adoption of new eating habits and lifestyles. In the midst of all these transformations, there is a complicating element a social apartheid, which marginalizes a quarter of the population ${ }^{8}$.

A retrospective analysis of the nutritional situation of the Brazilian population demonstrates that, until the 70s, the nutritional scene was clearly characterized by epidemic outbreaks of hunger,

\footnotetext{
1 Universidade Federal da Paraíba, Centro de Ciências da Saúde, Pós-graduação em Ciências da Nutrição, João Pessoa, PB, Brasil. 2 Ministério da Saúde do Brasil - Brasília-DF.

Corresponding author: alicetel@terra.com.br
}

Suggested citation: Carvalho AT et al. Nutritional situation of children under five years old in brazil's northeastern cities. Journal of Human Growth and Development, 24(2): 221-227

Manuscript submitted Oct 08 2013, accepted for publication Feb 222014. 
geographically and socially localized, with high indices of the prevalence of serious, severe forms of energetic-protein undernourishment (EPU). The following decade was, however, characterized by an overall deficit of micronutrients, prevailing throughout the country, and by the rapid decline of the prevalence of EPU. As from the 1990s, a stabilization of the prevalence of EPU is to be observed and the maintenance of the micronutrient deficiencies (with special emphasis on irondeficiency anemia and the diseases related to vitamin A deficiency), especially in some regions of the North and Northeast, and an increase in obesity, diabetes and dyslipedemias ${ }^{9}$.

Data of the National Demographic and Child and Women's Health Research Project (Pesquisa Nacional de Demografia e Saúde da Criança e da Mulher - PNDS), ${ }^{10}$ of the Nutritional Call of the Semiarid (Chamada Nutricional do Semiárido) ${ }^{11}$ and of the most recent Research into Family Budgets (Pesquisa de Orçamentos Familiares - POF) ${ }^{12}$ have shown that in the age group of from 1 to 5 years both the prevalence of chronic undernourishment and of overweight attained results of about $7 \%$, exceeding three-fold the acceptable reference value for this age group.

Infant obesity has been conspicuous as a serious present-day problem and the evidence shows that overweight during infancy may lead, on the long term, to cardiovascular and metabolic complications and may also affect the pattern of growth and development in adolescence ${ }^{13,14}$.

On the other hand, undernourishment represents a risk factor for the development of other lacks/ deficiencies such as anemia and vitamin A deficiency, especially in children of less than 5 years of age ${ }^{15,16}$. Among the factors related to nutritional deficiencies are income and schooling, and inadequate food consumption is an important determining factor of the nutritional condition of this population ${ }^{14-16}$.

Within this scenario, the social policies relating to feeding and nutrition in Brazil have mainly addressed the monitoring and recovery of the nutritional state of individuals, as also questions related to hunger ${ }^{17}$.

The programs to combat iron-deficiency anemia and of supplementation with megadoses of vitamin a - Vitamina A Mais - have as their main objective the eradication of these deficiencies in the vulnerable population. The Bolsa Família program, the Brazilian program for the conditional transfer of income, seeks to combat hunger, poverty and inequality, and presents among its conditions for participation the monthly follow-up of the growth of the children of less than 7 years of age ${ }^{18}$.

For the purpose of assessing the operation of two government programs of eating and nutritional safety (National Program of Vitamin A Supplementation (Programa Nacional de Suplementação de Vitamina A - PNVITA) and the Bolsa Família Program - PBF), the General Coordination of Feeding and Nutrition of the Brazilian Ministry of Health carried out research in three municipalities in the northeastern region of the country. Both the programs regard children of less than 5 years of age as one of the vulnerable groups and a focus of the activities undertaken.

Thus to get to know the nutritional situation of children of less than 5 years of age who reside in these municipalities is a fundamental part of the actions of monitoring and assessment of the adequacy of the actions implanted by these programs. Within this perspective, the objective of this study was to describe the nutritional condition of the children of under 5 years of age residing in these municipalities on the basis of the prevalence of overweight, weight deficit and height deficit found there.

\section{METHODS}

A cross-sectional epidemiological study was undertaken in three municipalities of the Northeastern Region of Brazil involving children of less than 5 years of age who constitute the target public of the two Brazilian programs of eating and nutritional safety.

The collection of data occurred on 9th August 2008 ('D-Day' of the second phase of the National Multivaccination Campaign), the date of the national mobilization to attain vaccination coverage for $100 \%$ of the infant public.

The area to be covered by the study was defined in two stages. The first related to the choice of the Northeastern region of the country, as this presented greater proportions of eating and nutritional insecurity ${ }^{10}$. The second sought to define the selection of the municipalities in the light of the coverage of the programs under analysis and the logistic feasibility of the research project (including the interest of the municipal managers in participating in the research and the availability of human and material resources for the data collection).

Thus the following municipalities were selected: 1) Tibau do Sul, in the State of Rio Grande do Norte - as it had a high degree of coverage of the monitoring of compliance with the health conditions for participation in the Bolsa Família Program, 2) Barra de São Miguel, in Alagoas State - by virtue of the low coverage of its monitoring of the health conditions for participation in the Bolsa Família Program, and 3) Cabedelo, in Paraíba State - as its coverage of the PNVITA stood in need of improvement.

The data collection was carried out at the vaccination posts installed in units of the Family Health Strategy (Estratégia de Saúde da Família), the model of the Primary Health Care adopted in Brazil.

A representative sampling of the children of below 5 years of age was undertaken in the three municipalities studied, using the procedure of sampling by conglomerate /cohort in two stages for the municipality of Cabedelo and sampling in one single stage in the other two municipalities. In Cabedelo, 15 of the 19 vaccination posts of the 1 st stage of the national campaign of 2008 were drawn for inclusion in the project. In both the other municipalities, all the posts were included. The 
selection of the sample of children took place systematically with the inclusion of one child of each three vaccinated, according to their order of arrival at the vaccination post ${ }^{19}$.

In accordance with the forecast of the number of children to be immunized at each vaccination post and in view of the almost universal coverage $(100.0 \%$ in Cabedelo, 96.2\% in Tibau do Sul and 92\% in Barra de São Miguel) of the $1^{\text {st }}$ stage of the vaccination campaign, the minimum number of children calculated to guarantee the representativeness of the sample was 1,018 . A prevalence of $15 \%$ of nutritional deviation, a confidence interval of $95 \%$ and a maximum sampling error of two percentage points were foreseen.

Thus a total of 1,378 children were assessed, 340 in Barra de São Miguel, 324 in Tibau do Sul and 714 in Cabedelo, representing $42.8 \%$, 30.3\% and $23.4 \%$, respectively, of the number of children immunized at the posts selected.

For the taking of the anthropometric measurements of the children of less than 5 years of age, students of the graduate courses of Nutrition and Physical Education of various higher education institutions of the participating States were selected and trained. The field work was accompanied by the team which was conducting the research, by representatives of the State and municipal health secretariats and by faculty members of the participating universities.

Some information was collected for the construction of the anthropometric indices and the later assessment of the nutritional state of the children: date of birth and of the undertaking of the anthropometric examination, sex, body weight and height. The measurements were taken twice in succession and the average result recorded on a standardized form.

Body weight was measured with a portable

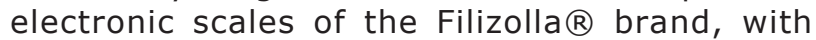
capacity for $150 \mathrm{~kg}$, calibrated to the nearest 100 g. The children were weighed wearing only their underclothes and barefoot. For the measurement of height, the children of more than 24 months of age were measured in the upright position with a vertical measuring rod, while the length of those of less than two years of age was measured in a dorsal decubital position with a horizontal pediatric measuring rod. Both these pieces of equipment were fitted with unstretchable measuring tape calibrated to the nearest $0.1 \mathrm{~cm}^{20}$.

The anthropometric indices height/age, weight/age and weight/height were calculated, according to their $Z$ score values. The World Health Organization's Infant Growth Curves were adopted for the nutritional assessment ${ }^{21}$. Deficit and excess in regard to the indicators assessed were considered to be, respectively, results below -2 and above +2 $Z$ scores. The data of the anthropometric survey were processed using the Anthro 2006 program.

None of the children who presented any congenital or acquired malformations or physical or mental deficiencies was considered eligible to participate. The anthropometric measurements were taken after those responsible had agreed to participate in the research project and signed the Voluntary and Informed Consent form.

The study was analyzed and approved by the Committee on Ethics in Research of the Health Science Center of the Federal University of Paraíba (Centro de Ciências da Saúde da Universidade Federal da Paraíba) under the protocols nos. 138/ 08 and 450/08.

\section{RESULTS}

The population studied presented similar characteristics in terms of distribution by age group and sex of the children in the three municipalities. (Table 1).

As regards the minimum, average and maximum ages of the children, the values found in the municipality of Barra de São Miguel were 03 days, 32 months, and 60 months, respectively. In Tibau do Sul, the results were quite similar: 06 days, 37 months, and 59 months, respectively. In Cabedelo, the minimum age was of 02 days, the average age 35 months, and the maximum age 60 months (data not given in tables).

Table 1: Distribution of children by sex and age group in the municipalities of Barra de São Miguel, Cabedelo and Tibau do Sul. Northeastern Brazil, 2008

\begin{tabular}{|c|c|c|c|c|c|c|}
\hline \multirow[t]{2}{*}{ Characteristics of the children studied } & \multicolumn{6}{|c|}{ Municipalities studied } \\
\hline & \multicolumn{2}{|c|}{ Barra de São Miguel } & \multicolumn{2}{|c|}{ Tibau do Sul } & \multicolumn{2}{|c|}{ Cabedelo } \\
\hline & \multicolumn{2}{|c|}{$\mathbf{n}$} & \multicolumn{2}{|c|}{$\mathbf{N}$} & \multicolumn{2}{|c|}{$\mathbf{n}$} \\
\hline Total & \multicolumn{2}{|c|}{340} & \multicolumn{2}{|c|}{324} & \multicolumn{2}{|c|}{714} \\
\hline Distribution by sex & $\mathbf{n}$ & $\%$ & $\mathbf{N}$ & $\%$ & $\mathbf{n}$ & $\%$ \\
\hline Feminine & 185 & 54.4 & 172 & 53.1 & 367 & 51.4 \\
\hline Masculine & 155 & 45.6 & 152 & 46.9 & 347 & 48.6 \\
\hline Distribution by age group & \multicolumn{2}{|c|}{$\%$} & \multicolumn{2}{|c|}{$\%$} & \multicolumn{2}{|c|}{$\%$} \\
\hline$<1$ year & \multicolumn{2}{|c|}{19.1} & \multicolumn{2}{|c|}{14.8} & \multicolumn{2}{|c|}{14.8} \\
\hline 1 year up to $<2$ years & \multicolumn{2}{|c|}{17.6} & \multicolumn{2}{|c|}{11.4} & \multicolumn{2}{|c|}{18.2} \\
\hline 2 years up to $<3$ years & \multicolumn{2}{|c|}{17.9} & \multicolumn{2}{|c|}{19.7} & \multicolumn{2}{|c|}{17.7} \\
\hline 3 years up to $<4$ years & \multicolumn{2}{|c|}{24.1} & \multicolumn{2}{|c|}{25.8} & \multicolumn{2}{|c|}{26.1} \\
\hline 4 years up to $<5$ years & \multicolumn{2}{|c|}{21.2} & \multicolumn{2}{|c|}{28.3} & \multicolumn{2}{|c|}{23.2} \\
\hline
\end{tabular}


As for the anthropometric indicators assessed, higher proportions of overweight for age $(<+2 D P)$ were observed $(8.3 \%$ in Barra de São Miguel, $10.3 \%$ in Cabedelo and $5.9 \%$ in Tibau do Sul) as compared with the proportions of deficit (<- 2DP) $(1.5 \%$ in Barra de São Miguel,
$1.9 \%$ in Cabedelo and $0.9 \%$ in Tibau do Sul). When the height/age indicator was assessed, percentages higher than $4 \%$ of children with a height deficit, above the percentages found in the deficit of weight to age (Table 2), were perceived.

Table 2: Distribution of the children of the municipalities of Barra de São Miguel, Cabedelo and Tibau do Sul, by anthropometic indices. Northeastern Brazil, 2008

\begin{tabular}{|c|c|c|c|c|}
\hline \multirow[t]{2}{*}{ Anthropometric indices } & \multirow[t]{2}{*}{ Classification of nutritional status a } & \multicolumn{3}{|c|}{ Municipalities studied } \\
\hline & & $\begin{array}{c}\text { Barra de } \\
\text { São Miguel }\end{array}$ & Cabedelo & $\begin{array}{c}\text { Tibau do } \\
\text { Sul }\end{array}$ \\
\hline Index & Deficit & 1.5 & 1.9 & 0.9 \\
\hline Weight/Height & Eutrophy & 90.2 & 87.8 & 93.2 \\
\hline$(\%)$ & Excess & 8.3 & 10.3 & 5.9 \\
\hline Index & Deficit & 3.6 & 2.5 & 1.5 \\
\hline Height/Age & Eutrophy & 91.1 & 90.5 & 95.4 \\
\hline$(\%)$ & Excess & 5.3 & 7.0 & 3.1 \\
\hline Index & Deficit & 5.9 & 5.5 & 4.6 \\
\hline Weight/Age & Eutrophy & 93.2 & 92.6 & 93.2 \\
\hline$(\%)$ & Excess & 0.9 & 1.9 & 2.2 \\
\hline
\end{tabular}

${ }^{\text {aDeficit }}=>-2 \mathrm{SD}$; Eutrophy $=-1>\mathrm{SD}>+1$; Excess $=<+2 \mathrm{SD}$

\section{DISCUSSION}

An unfavorable nutritional profile was observed in the group studied. This scenario is in agreement with that observed in the most recent surveys ${ }^{10-12,21-24}$ and with nationwide studies ${ }^{25-31}$ as well as with those undertaken in other Latin American countries ${ }^{3-7}$.

In this present study, the prevalences of overweight for height are greater than those of deficit, by as much as five to six times. These findings corroborate those of other studies $5-7,21,25,27$.

The comparative reading of Brazilian nutritional inquiries, undertaken over the last three decades, shows a marked decline in the prevalence of the weight deficit in children of less than 5 years of age. From 1974/75 to 2006, the prevalence of the deficit of weight for age diminished from $20.1 \% 22$ to $1.8 \%{ }^{10}$.

This reduction is also observed when one compares the prevalence of weight for height (W/ $\mathrm{H}$ ) obtained by the National Demography and Health Research Project (Pesquisa Nacional de Demografia e Saúde - PNDS), carried out in $1996-2.2 \%$ of $\mathrm{W} / \mathrm{H}$ deficit $^{24}$ - and in $2006-1.5 \%$ of $\mathrm{W} / \mathrm{H}$ deficit $^{10}$. Ferreira and Luciano ${ }^{25}$ on analyzing the nutritional status of children of less than 5 years of age in the State of Alagoas, found a prevalence of overweight for height eight times greater than the deficit of weight for height $(9.7 \%$ and $1.2 \%$, respectively). Álvarez et al. ${ }^{6}$ in a study conducted on children of from 6 to 60 months, of the city of Antioquia, Colombia, found percentages of overweight and deficit of weight for height of $3.8 \%$ and $2.0 \%$, respectively. Oyhenart et al. ${ }^{7}$ recorded a prevalence of overweight for height four times greater than of deficit ( $12.5 \%$ to $3.0 \%$, respectively) on analyzing the nutritional status of children of between 1 and 11 years of age of the city of La Plata, Argentina.

The study entitled "Health Care in Maranhão" ("Atenção à Saúde no Maranhão") ${ }^{33}$, undertaken in 2006/7 on children of less than 5 years of age, found prevalences of undernourishment by the indices weight/age $(4.5 \%)$ and weight/height $(3.9 \%)$ greater than those observed in this present study. It also found a prevalence of $6.7 \%$ of overweight for height, below those observed for the municipalities of Barra de São Miguel and Cabedelo, and greater than that observed in the municipality of Tibau do Sul.

Obesity is a public health problem in various populations and has presented high prevalences in ever younger age groups, which increases the risk of persistence and of the more serious comorbidities such as cardiovascular diseases, systemic arterial hypertension, diabetes milletus and some kinds of neoplasia ${ }^{34}$. Other complications arising from obesity among the youngest are mental disturbances, due generally to these individuals' not presenting the physical type expected by society, leading to discrimination, social exclusion and the consequent psychological disturbances such as depression and anxiety ${ }^{35}$.

This nutritional profile has been related to various determinants, especially those related to lifestyle, such as sedentary lifestyle (mainly due to time spent before the TV and/or the computer, to the detriment of the regular practice of physical exercise) and inadequate eating habits (especially the high consumption of manufactured foodstuffs and fast foods) ${ }^{36}$. These habits are at times influenced by the family atmosphere, where they should be regarded as problematic, so that healthier attitudes may be adopted with a view to changing the lifestyle. 
Regarding height deficit, De Onis ${ }^{37}$ observed that, in 2005, one-third of all the children below five years of age (about 178 million children) in low and medium income countries presented low height. Studies do, however, indicate a tendency to a decline both in the prevalence of low stature ${ }^{38}$ as in that of low weight ${ }^{37}$ in children, though such declines still fall short of the $50 \%$ reduction in undernourishment established as one of the Development Goals of the Millennium (MDM-1) ${ }^{39}$ Millennium Development Goals (MDGs) ${ }^{39}$ for the eradication of hunger. Monteiro et $\mathrm{al}^{40}$, on analyzing the data of four household research projects undertaken in Brazil (National Study of Household Expenditure - Estudo Nacional de Despesa Familiar - in 1974-1975; National Research Project on Health and Nutrition Pesquisa Nacional de Saúde e Nutrição - in 1989; and two projects on Demography and Health, in 1996 and 2006-2007) relating to the stature of children, perceived a continuous shift towards normal growth over time. The total prevalence of low stature in children in the four research projects was as follows: $1974-1975,37.1 \%$ (CI 95\%: 34.639.6); 1989, 19.9\% (CI 95\%: 17.8-21.9); 1996, 13.5\% (CI 95\%: 12.1-14.8) and 2006-2007, 7.1\% (CI 95\%: 5.7-8.5). Thus one perceives a reduction of more than $80 \%$ in the prevalence of low stature in children between 1974-1975 and 2006-2007.

Groeneveld, Solomons \& Doak ${ }^{5}$, Álvarez, López \& Estrada ${ }^{6}$, Oyhenart \& colleagues ${ }^{7}$ reported high prevalences in various Latin American countries and defined this as a public health problem which endures to the present day. When the prevalences of the deficits of weight/age and height/age in this present study are compared, the latter presents percentages greater than the former, indicating that, despite the scenario of acute undernourishment (characterized by the weight for age deficit) being under control, the height deficit still persists in children of less than five years of age.

Groeneveld, Solomons \& Doak ${ }^{5}$ found prevalences of the deficit of height for age varying between 5.8 and $27.7 \%$ in a population of schoolchildren of 8 to 10 years of age in the city of Quetzaltenango, Guatemala. High prevalences of height deficit (17.6\%) have also been described by Álvarez, López \& Estrada 6 . In Argentina, Oyhenart et al. ${ }^{7}$ and Pais $\&$ Carrera ${ }^{4}$ found prevalences of $15 \%$ and $7.5 \%$, respectively, in children and adolescents of the cities of La Plata and Santa Fé.

In Brazil, nutritional inquiries and studies such as that of Monteiro et al ${ }^{32}$ have found a tendency to decline in the prevalences of height deficit, despite this persisting at levels higher than $5 \%$. Results of the most recent Research Project on Household Budgets $^{12}$ registered prevalences of $6.3 \%$ and $5.7 \%$ in boys and girls of less than five years of age, having attained, respectively, $8.4 \%$ and $9.4 \%$, in the first year of life. For the Northeastern region, the prevalence found was of $5.9 \%$ of children of less than five years of age with a height deficit.

Chagas et $\mathrm{al}^{33}$ found a prevalence of low height for age greater than those observed in this study, with a percentage of $8.5 \%$ of children of less than five years of age residing in municipalities of Maranhão with a height for age deficit.

The height deficit is of a multicausal character and may be due to family income, profession, schooling, environmental factors (type of dwelling, sanitary conditions), reproductive aspects (mother's age, number and order of birth, interval between births), food consumption, food quality, concurrent diseases, access to health actions, among others ${ }^{41}$.

Prevalences of height deficit approximating to those obtained in this present study are reported by Ferreira et al. ${ }^{11}$ in the assessment of the Nutritional Call of the Semiarid (Chamada Nutricional do Semiárido), for the States of Rio Grande do Norte and Paraíba. Other studies conducted in various regions of the country ${ }^{25-29}$ found prevalences of stunting greater than those of this study, with a variation of from $6.7 \%$ (in children of 10 years of age in the city of Ferros, Minas Gerais, in the southeast of Brazil) ${ }^{27}$ to $12.3 \%$ (in children of 6 to 24 months of age resident in Acrelândia, in the State of Acre, in northern Brazil) ${ }^{28}$.

The high prevalences of stunted growth present in the traditional populations of Brazil, such as those of the quilombos (settlements which began as refuges for fugitive slaves) and indigenous tribes, are noteworthy. The National Quilombola Call (A Chamada Nutricional Quilombola) ${ }^{29}$ (a quilombola being an inhabitant of a quilombo) found a prevalence of $15 \%$ in the height deficit of children of less than five years of age. Concerning the indigenous population, Castro et al. ${ }^{30}$ found a prevalence of $15.5 \%$ among children of less than 10 years of age of the Kaingáng tribe of the south of Brazil. For the same age group, Mondini et al. ${ }^{31}$ observed prevalences of $28.2 \%$ and $15.06 \%$ in children of the Aruak and Karibe tribes, respectively.

In the light of what is set out above, it is necessary that the social equipment of the health and other areas, such as education, be prepared to deal with the profile of the nutritional transition of the population, incorporating into its daily routine preventive actions for the prevention of diseases and for the promotion of health. Thus, not only should actions of eating and nutritional education be fomented but especially actions which seek to guarantee the human right to adequate food, which include the promotion of physical and economic access to a healthy and diversified diet ${ }^{42}$, and actions of eating and nutritional surveillance responsible for the monitoring of the eating and nutritional situation of the population.

In brief, it is concluded that actions addressed to the promotion of adequate feeding should be prioritized within the scope of programs and policies of feeding and nutrition. The high prevalences of height deficit and of overweight highlight the vulnerability of this group (i.e, of children of less than five years of age) and the sum of these actions should produce an impact in reversing this nutritional profile. 


\section{REFERENCES}

1. Batista Filho M, Assis AM, Kac G. Transição nutricional: conceito e características. In: Kac G, Sichieri R, Gigante DP. Epidemiologia nutricional. Rio de Janeiro: Editora Fiocruz/ Atheneu; 2007. p. 445-60.

2. Organización Panamericana de la Salud. La obesidad en la pobreza: un nuevo reto para la salud publica. Washington, D. C.: OPS; 2000. (Publicación científica 576).

3. Moraes SA, Rosas JB, Mondini L, Freitas ICM. Prevalência de sobrepeso e obesidade e fatores associados em escolares de área urbana de Chilpancingo, Guerrero, México, 2004. Cad Saúde Pública 2006; 22:1289-301. http:// d x. do i . org/10.1590/S0102 $311 \times 2006000600018$.

4. Pais $A B$, Carrera EF. Necessidades básicas insatisfeitas, desnutrição infantil e risco de doenças na vida. Rev Paul Pediatr 2009; 27:127-32. http://dx.doi.org/10.1590/S010305822009000200002.

5. Groeneveld IF, Solomons NW, Doak CM. Nutritional status of urban schoolchildren of high and low socioeconomic status in Quetzaltenango, Guatemala. Rev Panam Salud Publica 2007; 22:169-77. http://dx.doi.org/ 10.1590/S1020-49892007000800003.

6. Álvarez MC, López A, Estrada A. Estado nutricional de niños de Antioquia, Colômbia, según dos sistemas de referencia. Rev Panam Salud Publica 2009; 25:196-203. http:// dx.doi.org/10.1590/S1020-4989200 9000300002.

7. Oyhenart EE, Torres MF, Quintero FA, Luis MA, Cesani MF, Zucchi M, Orden AB. Estado nutricional y composición corporal de niños pobres residentes en barrios periféricos de La Plata, Argentina. Rev Panam Salud Publica 2007; 22:194-201. http://dx.doi.org/10.1590/ S1020-49892007000800006.

8. Coutinho JG, Gentil PC, Toral N. A desnutrição e obesidade no Brasil: o enfrentamento com base na agenda única da nutrição. Cad Saúde Pública 2008; 24:332-40. http://dx.doi.org/ 10.1590/S0102-311X2008001400018.

9. Vasconcelos FAG. A epidemiologia das deficiências nutricionais no Nordeste: a contribuição de Malaquias Batista Filho à institucionalização da Nutrição em Saúde Pública no Brasil. Cad Saúde Pública 2000; 16:533-44. http://dx.doi.org/10.1590/S0102311X2000000200023.

10. Brasil. Ministério da Saúde. Pesquisa Nacional de Demografia e Saúde da Criança e da Mulher - PNDS 2006: dimensões do processo reprodutivo e da saúde da criança/ Ministério da Saúde, Centro Brasileiro de Análise e Planejamento. - Brasília: Ministério da Saúde; 2009.

11. Ferreira HS, Assunção ML, Florêncio TMMT, Lima MAA. Estado nutricional de pré-escolares da região semi-árida do Estado de Alagoas 2005. In: Chamada Nutricional: um estudo sobre a situação nutricional das crianças do semi-árido brasileiro. Cadernos de Estudos Desenvolvimento Social em Debate - N. 4 (2006). Brasília: Ministério do Desenvolvimento Social e Combate à Fome, Secretaria de Avaliação e Gestão da Informação; 2005. p. 37-42.

12. Instituto Brasileiro de Geografia e Estatística. Pesquisa de orçamentos familiares 2008-2009. Antropometria e análise do estado nutricional de crianças, adolescentes e adultos no Brasil. Rio de Janeiro: IBGE; 2010.

13. Menezes RCE, Lira PIC, Oliveira JS, Leal VS, Santana SCS, Andrade SLLS et al. Prevalence and determinants of overweight in preschool children. J Pediatr. 2011;87(3):231-7. http:// dx. doi. org/10.1590/S0021-755720110003 00009.

14. Marcovecchio ML, Chiarelli F. Obesity and Growth during Childhood and Puberty. World Rev Nutr Diet. 2013;106:135-41. doi: 10.1159/ 000342545.

15. Gondim SSR et al. Relação entre níveis de hemoglobina, concentração de retinol sérico e estado nutricional em crianças de 6 a 59 meses do Estado da Paraíba. Rev. Nutr. 2012; 25(4):441-9. http://dx.doi.org/10.1590/ S1415-52732012000400002.

16. Paiva AA, Rondó PHC, Reinaldo LGC et al. The effect of vitamin A supplementation on retinol concentrations of children with anaemia. Nutr Hosp. 2012;27(6):2151-2. doi: 10.3305/ nh.2012.27.6.6141.

17. Uchimura KY, Bosi MLM. Programas de comercialização de alimentos: uma análise das modalidades de intervenção em interface com a cidadania. Rev Nutr 2003; 16(4): 387-97. http: //dx.doi.org/10.1590/S141552732003000400002

18. Brasil. Ministério do Desenvolvimento Social e Combate à Fome. Programa Bolsa-Família. 2014. Disponível em http://www.mds.gov.br. [Acessado em 14 de março de 2014]

19. Carvalho AT, Almeida ER, Nilson EAF, Ubarana JA, Fernández IM, Immink M. Métodos de análise em programas de segurança alimentar e nutricional: uma experiência no Brasil. Ciênc. saúde coletiva 2013; 18:309-21. http:// dx.doi.org/10.1590/S1413-812320130 00200003.

20. Ministério da Saúde. Vigilância alimentar e nutricional - SISVAN: antropometria: como pesar e medir / [Denise Cavalcante de Barros et al.] - Brasília: Ministério da Saúde; 2004.

21. World Health Organization. WHO Child Growth Standards: length/height for-age, weight-forage, weight-for-length, weight-for-height and body mass index-forage: methods and development. Geneva: WHO; 2006.

22. Instituto Brasileiro de Geografia e Estatística. Estudo Nacional de Despesa Familiar (ENDEF). Rio de Janeiro: IBGE; 1974.

23. Instituto Nacional de Alimentação e Nutrição. Pesquisa Nacional sobre Saúde e Nutrição. Perfil de Crescimento da População Brasileira de 0 a 25 anos - PNSN. Brasília: INAN; 1989.

24. Instituto Brasileiro de Geografia e Estatística. Sociedade Civil Bem-Estar Familiar no Brasil. 
Pesquisa Nacional sobre Demografia e Saúde PNDS; 1996. Rio de Janeiro: IBGE; 1996.

25. Ferreira HS, Luciano SCM. Prevalência de extremos antropométricos em crianças do estado de Alagoas. Rev Saúde Pública 2010; 44:377-80. http://dx.doi.org/10.1590/S003489102010005000001.

26. Laurentino GEC, Arruda IKG, Raposo MCF, Batista Filho M. Déficit estatural em crianças em idade escolar e em menores de cinco anos: uma análise comparativa. Rev Nutr 2006; 19:157-67. http://dx.doi.org/10.1590/S141552732006000200003.

27. Felisbino-Mendes MA, Campos MD, Lana FCF. Avaliação do estado nutricional de crianças menores de 10 anos do município de Ferros, Minas Gerais. Rev Esc Enferm USP 2010; 44:257-65. http://dx.doi.org/10.1590/S008062342010000200003.

28. Garcia MT, Granado FS, Cardoso MA. Alimentação complementar e estado nutricional de crianças menores de dois anos atendidas no Programa Saúde da Família em Acrelândia, Acre, Amazônia Ocidental Brasileira. Cad Saúde Pública 2011; 27:305-16. http://dx.doi.org/ 10.1590/S0102-311X2011000200012.

29. Taddei JA, Colugnati F, Cobayashi F. Chamada nutricional: uma avaliação nutricional de crianças quilombolas de 0 a 5 anos. In: Políticas sociais e Chamada Nutricional Quilombola: estudos sobre condições de vida nas comunidades e situação nutricional das crianças. Cadernos de Estudos Desenvolvimento Social em Debate - N. 9 (2008). Brasília: Ministério do Desenvolvimento Social e Combate à Fome, Secretaria de Avaliação e Gestão da Informação; 2008. p. 55-66.

30. Castro TG, Schuch I, Conde WL, Veiga J, Leite MS, Dutra CLC, Zuchinali P, Barufaldi LA. Estado nutricional dos indígenas Kaingáng matriculados em escolas indígenas do Estado do Rio Grande do Sul, Brasil. Cad Saúde Pública 2010; 26:1766-76. http://dx.doi.org/10.1590/ S0102-311X2010000900010.

31. Mondini L, Rodrigues DA, Gimeno SGA, Baruzzi RG. Nutritional status and hemoglobin values of Aruak and Karibe Indian children - Upper Xingu, Central Brazil, 2001-2002. Rev Bras Epidemiol 2009; 12:1-8. http://dx.doi.org/ 10.1590/S1415-790X2009000300015.

32. Monteiro CA, Benicio MHDA, Konno SC, Silva ACF, Lima ALL, Conde WL. Causas e declínio da desnutrição infantil no Brasil, 1996-2007. Rev Saúde Pública 2009; 43:35-43. http:// d x.doi .org/10.1590/S0034 89102009000100005.

33. Chagas DC, Silva AAM, Batista RFL, Simões VMF, Lamy ZC, Coimbra LC, Alves MTSSB.
Prevalência e fatores associados à desnutrição e ao excesso de peso em menores de cinco anos nos seis maiores municípios do Maranhão. Rev Bras Epidemiol 2013; 16: 146-56. http:// dx.doi.org/10.1590/S1415-790X2013 000100014.

34. Miech RA, Kumanyika SK, Stettler N, Link BG, Phelan JC, Chang VW. Trends in the association of poverty with overweight among US adolescents, 1971-2004. JAMA 2006; 295:2433. http://dx.doi.org/10.1001/jama. 295. 20. 2385.

35. Kim B, Park MJ. The Influence of weight and height status on psychological problems of elementary schoolchildren through child behavior checklist analysis. Yonsei Med J 2009; 50:340-4. http://dx.doi.org/10.3349/ymj. 2009.50.3.340.

36. Leal VS, Lira PIC, Oliveira JS, Menezes RCE, Sequeira LAS, Arruda Neto MA, Andrade SLLS, Batista Filho M. Excesso de peso em crianças e adolescentes no Estado de Pernambuco, Brasil: prevalência e determinantes. Cad. Saúde Pública 2012; 28:1175-82. http:// d x. do i . org/10.1590/S0102 $311 \times 2012000600016$.

37. De Onis, M. Child undernutrition based on the new WHO growth standards and rates of reduction to 2015 . SCN News 2008; 36: 12-6. Disponível em: <http://www.unscn.org/layout/ modules/resources/files/scnnews36.pdf $>$. Acesso em: 21 dez. 2013.

38. De Onis M, Blössner M, Borghi E, Frongillo EA, Morris R. Estimates of global prevalence of childhood underweight in 1990 and 2015. JAMA 2004; 291: 2600-6. http://dx.doi.org/10.1001/ jama.291.21.2600.

39. UNITED NATIONS. The Millennium Development Goals. United Nations, 2008. Disponível em: <http://www.un.org/millenniumgoals>. Acesso em: 21 dez. 2013.

40. Monteiro CA, Benicio MHA, Conde WL, Konno SC, Lima ALL, Barros AJD, Victora CG. Desigualdades socioeconômicas na baixa estatura infantil: a experiência brasileira, 19742007. Estud.av. [online] 2013; 27: 35-49. http://dx.doi.org/10.1590/S010340142013000200004.

41. Rissin A, Figueiroa JN, Benicio MHA, Batista Filho M. Retardo estatural em menores de cinco anos: um estudo "baseline". Ciênc. saúde coletiva 2011; 16:4067-76. http://dx.doi.org/ 10.1590/S1413-81232011001100012.

42. Casemiro JP, Valla VV, Guimarães MBL. Direito humano à alimentação adequada: um olhar urbano. Ciênc. saúde coletiva $2010 ; 15: 2085-$ 93. http://dx.doi.org/10.1590/S141381232010000400022. 